\title{
Matching Imitative Activity of High-Tech Firms with Entrepreneurial Orientation
}

\section{Marta Najda-Janoszka*}

\begin{abstract}
As pointed by numerous scholars high technology sectors are very apt for studying entrepreneurial activities due to their high levels of innovativeness. However, taking into account the highly dynamic and substantially hostile environment in those sectors, innovation may often not be the best strategic choice for market entry. In fact, the business practice confirms the extensive utilization of imitation strategy by technology entrepreneurs Meanwhile, the literature on entrepreneurship focuses almost exclusively on original innovators, underestimating the importance of imitation in the growth process and indicating shortage of research on imitative activities of entrepreneurs. Therefore this article presents discussion on the applicability of entrepreneurial orientation to imitators from the high-tech industries.
\end{abstract}

Keywords: imitation, high-technology firms, entrepreneurial orientation

\section{Introduction}

Rapid technological progress strengthens competitive pressure and creates a rich pool of technological opportunities that encourage entrepreneurial behavior of firms (Lindelof \& Lofsten, 2006). However, taking into account the accelerating pace of imitation in high-technology sectors it has to be considered whether an entrepreneurial orientation should be assigned only to the first movers. In the literature entrepreneurship is tightly linked with innovation, in the sense that innovativeness represents the fundamental and necessary condition for the entrepreneurial orientation, yet the concept of innovation is not limited to the first practical use of the solution but also applies to products, processes, methods assimilated from other entities (Oslo Manual, 2005, p. 53). In fact, in high-tech industries the boundaries between the innovation and imitation are often blurred. Hence, following the pioneer does not eliminate risk of market entry and is not necessarily equal to lack of capabilities, weak market position or inability to recognize market opportunities. Nevertheless, the literature on entrepreneurship focuses almost exclusively on original innovators, underestimating the importance of imitation in the growth process and indicating shortage of research on imitative activities of entrepreneurs (Schmitz, 1989). Meanwhile the business practice confirms the extensive utilization of imitation

\footnotetext{
* Marta Najda-Janoszka, Ph.D., Department of Management in Tourism, Jagiellonian University in Krakow, ul. S. Łojasiewicza 4, Krakow, Poland, e-mail: marta.najda-janoszka@uj.edu.pl.
} 
strategy by entrepreneurs (Baumol, 1986 after: Schmitz, 1989, p. 722; Droege \& Dong, 2008) - "while entrepreneurial activity focuses on actualizing promising opportunities, the strategies and actions by which many entrepreneurial firms do so are best described as imitation strategies" (Droege \& Dong 2008, p. 51). This indicates the need for broadening the scope of theoretical analysis of entrepreneurial activity by including both strategic approaches to innovation. Since there are two alternative paths for seizing market opportunities, the key managerial decision concerns selecting the most appropriate strategy in a given context. The specificity of the highly innovative and dynamically growing high-tech industry calls for a particular attention in the subject area. Therefore this article presents discussion on the applicability of entrepreneurial orientation to imitators from the high-tech industries.

\section{Entrepreneurial orientation concept in high-tech industry}

Entrepreneurial orientation (EO) is based on the assumption that firms undertaking entrepreneurial activity can be distinguished from other firms by measurable features (Bednarczyk, 2010, p.19-31). Findings of early research indicated that entrepreneurial firms are more risk prone than other types of firms. Further additional features were developed such as entrepreneurs' need for achievement, internal locus of control (personality characteristics), strong emphasis on product innovation, aggressive competition with rival firms, proactive searching and seizing new business opportunities (Palich \& Bagby, 1995, p. 427; Park, 2005, p. 741; Kreiser, Marino, Weaver, 2002 , p. 73). The growing number of identified attributes and inconclusive empirical support for some of them called for an integrative approach in a form of a cohesive entrepreneurial orientation concept. The first conceptualization of EO was developed by Miller (1983), who defined an entrepreneurial firm as one that "engages in product market innovation, undertakes somewhat risky ventures and is first to come up with proactive innovations, beating competitors to the punch" (Miller, 1983, p. 771). This proposition was further adopted and operationalized by numerous researches. Among several propositions an operationalization developed by Covin and Slevin became the most widely utilized in entrepreneurship research (Covin \& Slevin, 1988 after: Kreiser, et al. 2002; Droege \& Dong, 2008). According to their suggestion the entrepreneurial orientation of a firm as an aggregate measure should be calculated by summing together the levels achieved by this firm in each of the three dimensions of the EO (Covin \& Slevin, 1988, after Kreiser, et al. 2002):

- Innovation - in entrepreneurship literature innovation is recognized as the fundamental undertaking of the entrepreneurial organization. According to Covin and Miles (1999) innovation underlines all forms of entrepreneurship, representing the most important of the three dimensions. A strong commitment to the process of creating and introducing new value to the market distinguishes an entrepreneurial firm from organizations with different strategic orientation (Zahra, 1993, p. 47). Thus, in order to meet the criteria set for entrepreneurial organization a firm should develop a higher than a given 
industry average number of new products or markets (Kreiser, et al. 2002, p. 74). Moreover, recent studies on entrepreneurial innovation increasingly include also non-technical innovations concerning new marketing and organizational methods, new business models.

- Risk-taking - while risk taking is attributable to any business activity, since all managerial decisions are risky because their outcomes are distant in time, entrepreneurial firms tend to be more risk prone than other firms. The observation that entrepreneurs are attracted to risky ventures with expected above-average outcomes formed the basis for the first formal theory of entrepreneurship (Palich \& Bagby, 1995, p. 426). However, willingness to engage in risky ventures does not mean that entrepreneurs accept greater levels of uncertainty, rather they have lower risk perception (Palich \& Bagby, 1995). "Entrepreneurs may not think of themselves as being any more likely to take risks than non-entrepreneurs, but they are nonetheless predisposed to cognitively categorize business situations more positively" (Palich \& Bagby, 1995, p. 426). According to Simon, Houghton and Aquino (2000) the low level of perceived risk exhibited by entrepreneurs could be due to the cognitive biases such as overconfidence, illusion of control and belief in law of small numbers.

- Proactiveness - this dimension received significantly less attention in the entrepreneurship literature than the previous two (Kreiser, et al. 2002, p.78). Lumpkin and Dess (2001) define proactiveness as opportunity-seeking perspective involving aggressive interaction with the environment, in particular competitors. Therefore entrepreneurial proactiveness has two features: an aggressive competition with rival firms and an organizational pursuit of favorable business opportunities (Kreiser, et al. 2002, p. 78). Some researchers extracted competitive aggressiveness as a distinct dimension of EO but such approach did not receive a wider support in the literature (Droege $\&$ Dong, 2008). The studies confirmed that entrepreneurs are more active in seeking opportunity than corporate managers, as they have the capacity to see what others do not (Timmons, 1999, after: Park, 2005, p. 742). According to the literature a prior experience of an entrepreneur is the prominent factor of the opportunity recognition process (Shane, 2000) - between 50 and $90 \%$ of startup ideas come from prior work experience (Hills, Shrader, Lumpkin, 1999, after: Park 2005, p. 742). Other potential factors mentioned in the literature such as personality traits and social networks require further research to confirm their validity (Park, 2005, p. 747).

Further studies focused on the development of the EO operationalization resulted in a fundamental change in hitherto widely adopted assumption. The research work conducted by Lumpkin and Dess (1996) and Kreiser et al. (2002) led to the conclusion that, although these three dimensions comprise a single measure, they equally represent individual components of EO having individual contributions to firm performance 
as well as independent interactions with environmental variables. It undermined the commonly utilized assumption of uni-dimensional, aggregated character of EO measure by proving its multi-dimensionality (Kreiser, et al. 2002). Further, the strict requirement of exhibiting high levels of each dimension in order to be recognized as an entrepreneurial firm was significantly relaxed. It was found that various combinations of the three dimensions can equally shape the EO of a given firm. (Kreiser, et al. 2002; Lumpkin \& Dess, 1996).

As pointed by numerous scholars, high technology sectors (High..., 2009) are very apt for studying entrepreneurial activities. In those sectors rapid technological change creates a rich pool of technological opportunities that encourages entrepreneurial firmlevel behavior and enables the successful entry of new firms (Lindelof \& Lofsten, 2006). According to Park (2005) in markets characterized by a rapid technology advancing barriers resulting from the lack of critical mass of newly established firms are practically negligible. However, as argued by Granstrand (1998) the high-technology firms face knowledge-based barriers since they need a specialized managerial knowledge to locate, mobilize, combine and exploit other resources in response to business opportunities. In dynamic technological markets entrepreneurial firms play a more prominent role than in sectors fully occupied by large firms with established knowledge base, R\&D budgets, accumulated experience that enable engaging in large scale innovations (Park, 2005, p. 741). Due to the dynamic technology development emerging entrepreneurial firms can challenge established positions with good prospects of success. Indeed, often "radical new technologies render the competencies of incumbent firms obsolete leaving them locked into existing technological trajectories and outdated business propositions" (Cefis \& Marsili, 2011, p. 478). This observation is consistent with the conclusion formulated by Sorensen and Stuart (2000), according to which aging is associated with increases in high-tech firms' rates of innovations, but the scope of their innovative activities frequently becomes limited to local areas of expertise in particular domain of business activity and leads to competency traps thus threatening the environmental fit of those companies. In high-technology markets in order to innovate firms are forced to invest heavily in competence development in particular areas of technology which in turns causes strategic inertia on the adaptive potential of those firms to important changes in technological regimes (Sorensen \& Stuart, 2000, p. 87). Nevertheless participation in the innovation race is a necessity for the firms operating in the high-tech industry even though it does not spectacularly improve their chances of survival (Cefis \& Marsili, 2011). Those firms need to innovate just to maintain their positions (Cefis \& Marsili, 2011). "High-tech firms work in a truly extreme environment where the technology challenges are often on the edge of scientific possibility, but with the available resources generally scarce" (Park, 2005, p. 741). In the academic literature these extreme external conditions are most often described by using environmental dynamism and environmental hostility dimensions. Environmental dynamism refers to "the rate of change and innovation in an industry as well as the uncertainty and predictability of the actions of competitors and customers" (Miller \& Friesen, 1983, p. 222). According 
to Khandwalla (1977, p. 27) a hostile environment is "a risky, stressful and dominating environment with precarious industry settings and intense competition". Zahra and Neubaum (1998) identified four levels of environmental hostility:

- Macro level related to political, regulatory and economic conditions,

- Market level referring to unfavorable conditions that exist within the industry,

- Competitive level related to the intensity of competition in a given industry and aggressiveness of actions taken to gain opportunities,

- Technological level referring to radical changes in technological resources and capabilities available within the industry.

It is widely supported in the literature that highly dynamic environment, by creating numerous opportunities, provide a strong impetus to take risk (Covin \& Slevin, 1991; Khandwalla, 1977). In case of hostility dimension the relationship between organizational risk-taking and level of environmental hostility tend to be curvilinear as the organizational risk-taking is the highest at moderate levels of environmental hostility (Kreiser ). Extreme hostile conditions discourage firms from taking risks that would erode their profits. Equally benign environments do not provide incentives for risk-taking as conservative strategies ensure sustaining positions. Consequently, in highly dynamic and considerably hostile environments that characterize high-technology sectors quick and risky actions are necessary to maintain the chances of survival (Park, 2005). Technological companies facing such external adversity and abundance of opportunities are more likely to undertake entrepreneurial activities to deal with dynamic, hardly predictable changes (Zahra \& Neubaum, 1998). Since effective opportunity recognition in the high-tech industries is determined by technology advancement and diversification, entrepreneurial firms pursuing business opportunities need to embrace this multidirectional technology development, "combine it with either new or existing market opportunities and continually evolve the technology with market or customer needs (Park, 2005, p. 745). One technology can give rise to multiple opportunities (Shane, 2000) as well as minor technology transferred from other business sector can become a high-value component of a spectacular new business venture (Park, 2005, p. 742).

\section{Imitation as a market entry strategy}

There are not many publications in which imitation is considered on par with other strategic options without negative connotation. The literature is dominated by dismissive attitude towards imitative activity of firms (Schmitz, 1989; Schnaars 1994; Shenkar, 2010; Schewe, 1996) even though imitation is "actually a much more prevalent road to business growth and profits" (Schnaars, 1994, p. 1). Thus, the business practice indicates that innovation and imitation are utilized as alternative pathways to successful business performance (Teece, 2002). Hence, the choice of market entry strategy should be considered in terms of managerial decision which involves in-depth analysis of potential benefits and drawbacks of each available option.

The limited attention devoted to imitation is primarily focused on illegal copying of original products. This adds up to a widespread bad impression of imitation 
as a criminal activity and leaves out of sight a whole spectrum of different forms of imitative practices. The literature does not provide many sophisticated typologies of imitation that would reflect the diversity of such activity. The most common approach is to distinguish two main types: pure imitation (Lee, Zhou, 2012) or duplicative imitation (Luo, Sun, Wang, 2011) and creative imitation (Lee, Zhou, 2012) or innovative imitation (Luo et.al 2011). However according to Schnaars (1994) imitation is exercised in different forms that can be arranged along the creativity continuum with counterfeits on one extreme and original innovations involving the highest degree of creativity and experimentation at the other (Figure 1):

- Counterfeits - illegal duplicates carrying the same brand name or trademark as the original product;

- Knockoffs - close legal copies of original products carrying their own brand names developed due to absence or expiration of legal protection (patents, copyrights) of competitors' products;

- Design copies - copies of style, design of competitor's product carrying its own brand name and possessing its own unique engineering specifications, may be based on a unique and innovative technology;

- Creative adaptations - creative improvements of competitor's products, adaptations of existing ideas to new applications as well as truly innovative solutions merely inspired by competitor's offering.

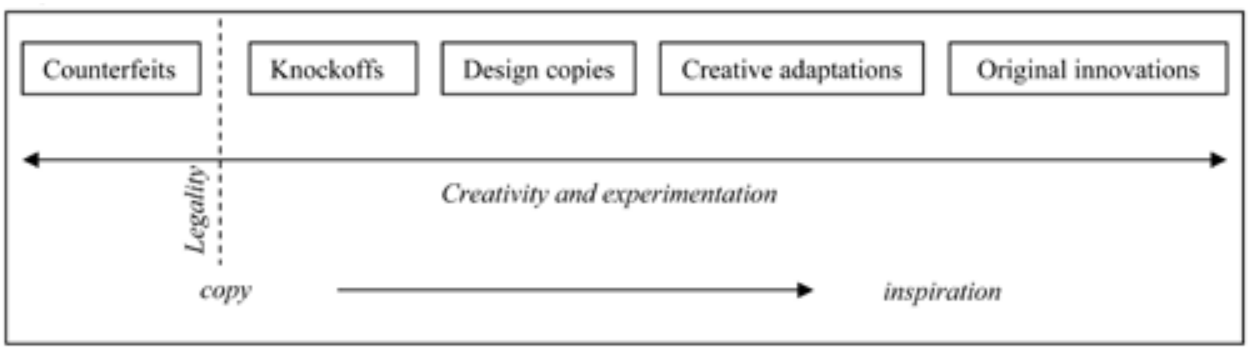

Figure 1. Imitation forms

Source: Author's own work based on Schnaars (1994).

The content of different kinds of imitative practices indicates the existence of potential for direct knowledge production that sometimes blurs the boundaries between imitations and original innovations (Schmitz, 1989; Shenkar, 2010). In the literature it is a widely used practice to reserve term innovator for a company that commercializes a novel value for the first time while launching this particular innovation in a new context by another company is recognized as an imitative behavior (Fagerberg, 2005 , 8). However, according to approach presented in Oslo Manual the concept of innovation is not limited to the first practical use of the solution but also applies to product, processes, methods assimilated from other entities and adapted to a new context (Oslo Manual, 2005, p. 53). Consequently creative adaptations are often 
equated with incremental innovations, whereas as pointed by Luo et al. (2011) these activities differ from each other since incremental innovations improve on a firms' own original product and creative adaptations add value to products introduced by other units. Nevertheless, assuming that "every new innovation consists of a new combination of existing ideas, capabilities, skills, resources" (Fagerberg, 2005, p. 10), it has not been defined at which point the creative adaptation ends and starts the novel innovation. Hence, the essential problem concerns proper distinguishing between related but distinct positions of pioneers, innovators, imitators and late market entrants. There are two main criteria used for the correct identification of them: the originality of the value created and introduced to the market, and the sequence in time of market entry (Schnaars, 1994, p. 12-13) (Figure 2).

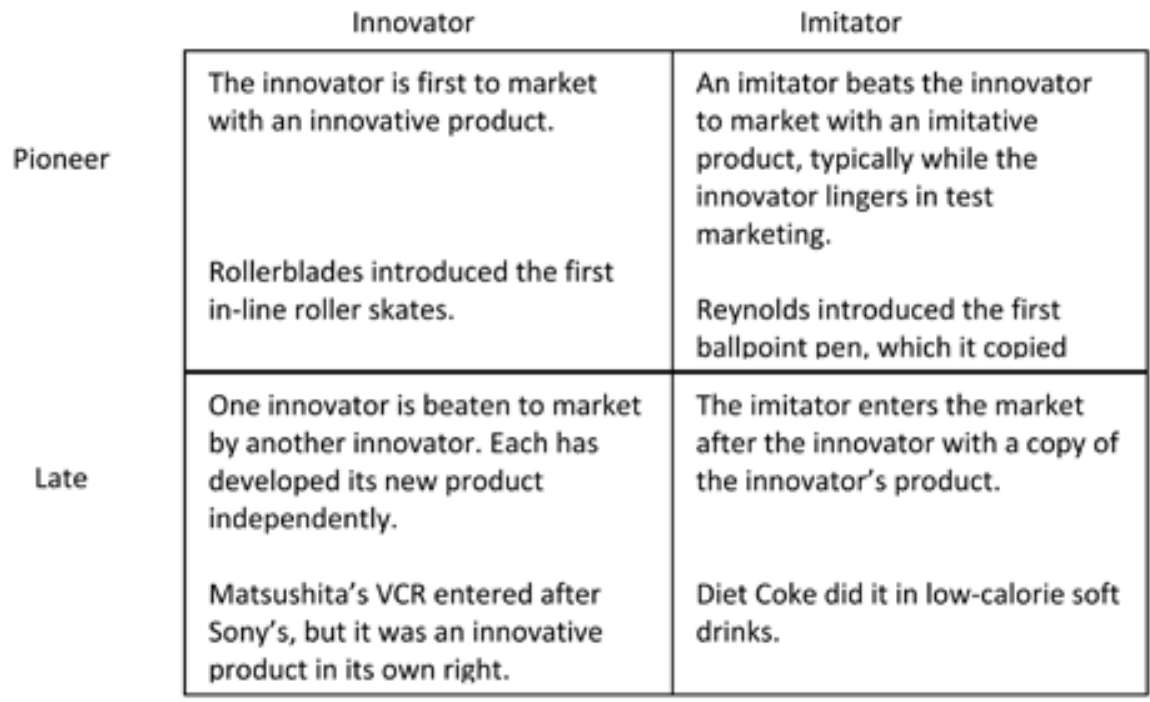

Figure 2. Imitation versus later entry Source: ( Schnaars, 1994: 12).

Thus, according to the resulting two-dimensional matrix imitators can be found among late entrants as well as pioneers when they manage to enter the market with copied solution before the original innovation passes the commercialization phase. Hence, being innovator does not exclude the possibility of late entry to the market. Parallel but independent development of a highly similar solution is not a rare case in business practice (Schnaars, 1994). Consequently, the distinction between imitators and late-entry innovators is not always clear. Equally difficult is to define a pioneer in actual case stories observed in high-technology industries where for one innovative category there is a bundle of potential pioneers in the pursuit of market success.

Undoubtedly achieving market success is the main goal of the market entry and, what is important, profiting from the new value is neither restricted nor guaranteed to first-movers. In fact economic reality indicates that an advantageous position of 
pioneers, commonly proclaimed on the theoretical ground, is significantly overstated (Teece, 2002; Shenkar, 2010) (Table 1). As bluntly stated by Gibson "the trouble with being a pioneer is that the pioneers get killed by the Indians" (Schnaars, 1994, p. 20). It is not a rare case when shortly after a successful commercialization pioneer gets push out from the established market position by the followers (Teece, 2002; Shenkar, 2010; Schnaars, 1994). Unfortunately the majority of discussions on the problem of profiting from innovative value are narrowed to the innovator-pioneer perspective and focused on the value appropriation strategy based on the management of value protection mechanisms (Fischer, 2011; Teece, 2002). Since innovation process provide opportunities for both pioneers and followers (Teece, 2002, p. 123), there is an apparent deficit of research containing analyses of different market entry strategies treated as alternative pathways to market success (Lee, Zhou, 2012). Knowledge about the specificity of each alternative strategy forms the basis for managerial decision on selecting the most appropriate market entry strategy in the given internal and environmental circumstances.

Table 1. Advantages of first-movers and followers

\begin{tabular}{|c|c|}
\hline First-movers & Followers \\
\hline $\begin{array}{l}\text { - Image derived from early entry } \\
\text { - Creating brand loyalty } \\
\text { - Technological leadership, experience } \\
\text { effects } \\
\text { - Setting product standards } \\
\text { - Determining distribution channels } \\
\text { - Legal protection of innovation }\end{array}$ & $\begin{array}{l}\text { - Image created through fast adapting to market } \\
\text { development } \\
\text { - Lowering the price and improving the quality through } \\
\text { product upgrading, } \\
\text { - Lower costs of educating customers } \\
\text { - Technological leapfrogging } \\
\text { - Avoiding lock-in with irreversible investments before } \\
\text { development of the dominant design } \\
\text { - lower R\&D expenditures and shifting capital to } \\
\text { marketing } \\
\text { - use of knowledge leakages, inventing around, reverse } \\
\text { engineering }\end{array}$ \\
\hline
\end{tabular}

Source: Author's own work based on Schnaars (1994), Teece (2002).

The analysis of available research works on imitation and innovation allowed for identification of conditions forming a favorable environment for implementing the imitator strategy in high-tech sectors:

- low degree of intellectual property protection - The impact of intellectual property regimes is rather confined to a fairly narrow segment of the economy (Teece, 2002, p. 116). Hence, as declared by managers, the level of legal protection afforded to innovative products is in most cases ineffective (Mansfield, 1985; Fischer, 2011). An empirical study of Mansfield (1985) found that patents commonly recognized as the most powerful legal protection mechanism and a symbol of innovation, in practice are not a very challenging barrier to imitators. Within four years 60 percent of the patented products covered by the study have been copied (Mansfield, 1985). Therefore, an 
extensive usage of patents in high-tech sectors is based not only on their limited protective power but even more likely due to their strategic function in strengthening the bargaining power of firms in cross-licensing. Developing hightech products requires multiple sourcing of industry knowledge and building a wide patent portfolio protects firms more often against claims of intellectual property infringement rather than imitative practices of competitors (Fischer, 2011).

- inherent immitability of the new value - Advancement in information processing provides better perspectives for knowledge codification and further accelerates its transfer and diffusion. The greater range of codified knowledge about innovation the better chances for imitation (Teece, 2002). According to Mansfield (1985) information about new R\&D projects tends to leak out to competitors within 12-18 months. Assuming that it takes on average three years to translate an idea into an innovative product ready for market introduction, then "there is a better-than-even chance that the decision [to innovate] will leak out before innovation is half-completed" (Mansfield, 1985, p. 219). The studies indicate that product and marketing innovations are more easily copied since their knowledge content is readily observable to competitors. In hightech sectors it is a common practice to utilize reverse engineering to learn the new solutions. However, process innovations are more immune to such practices since being not as much visible they do not reveal how their unique characteristics have been obtained (Teece, 2002).

- breakthrough innovation rendering existing industry standards obsolete Introducing a radical innovation to the market initiates the battle for setting the new industry standard (e.g. VHS - Betamax, HD-DVD - Blu-ray). An opportunity to set or have a significant contribution to a new industry standard attracts imitators since "the best initial design concepts often turn out to be hopelessly wrong" (Teece, 2002, p. 98). In their search for dominant design imitators modify the innovative product relying on the breakthrough solutions pioneered by the innovator. According to Teece $(2002$, p. 98) "when imitation is possible and occurs in conjunction with design modification before the emergence of a dominant design, followers have a good chance of having their modified product anointed as the industry standard, often to the great disadvantage of the innovator". Once a dominant design emerges the competition shifts from design fundamentals to price, thus making again room for imitators that introduce improvements providing lower prices and/or better quality of the initial innovation (Teece, 2002, p. 97).

- modularization of the innovators' value chains - Modularization lowers the threshold for entering technology and capital intensive markets (Shenkar, 2010 , p. 48). The knowledge and resource base formerly maintained within the boundaries of the firm is being more and more dispersed through intensive usage of modularization and outsourcing strategies. Technological expertise 
is therefore in the hands of module suppliers. Hence, modularity enables innovation at a distance from the focal firm (Henkel and Baldwin 2009). Thus, as observed in high-tech sectors in particular, by modularizing focal firms open itself up to potential competition from the module suppliers that may outperform the integrator (IBM - Microsoft, Intel) as well as to imitation from competitors contracting high value components from the same module suppliers (Henkel \& Baldwin, 2009; Shenkar, 2010; Afuah, 2010).

- access to complementary assets - Technological innovations are characterized by strong functional interrelatedness and dependencies between their internal sub-systems and incumbent solutions. Therefore successful innovation requires a careful management of those linkages to complementary technologies, e.g. entering the market with new data storage technology requires availability of its complementary readers. In high-tech industries complementary assets are very often more important than the innovation itself (Teece, 2002, p. 108). Thus, possession or reliable access to specialized complementary assets significantly increases the potential of extracting profits from innovations. Since small pioneering firms rarely have at their disposal necessary specialized assets the richly endowed large later entrants in most cases prevail those small upstarts (Schnaars, 1994). "Because the market of complementary assets is itself riddled with imperfections, competitive advantage can be gained or lost on how expertly the strategy for gaining access is executed" (Teece, 2002, p. 25).

Taking into account the conditions presented above innovation may not be the best strategic choice for market entry. After deciding to follow and surpass the firstmover a potential imitator needs to define how to realize this goal, whether by offering lower prices than the pioneer, selling a superior product in terms of its functionality and quality, or using market power to prevail the smaller pioneer. As evidenced in case studies presented by Schnaars (1994) and Shenkar (2010) imitators most often utilize a combination of those three options.

\section{Entrepreneurial orientation of high-tech imitators}

A thorough observation of business activity in the high-tech industries leads to the conclusion that imitation is becoming more feasible, more beneficial and faster than ever before (Shenkar, 2010, p. 168). The impact of various imitative practices on knowledge diffusion and development of high-tech industries forces to consider the strategic function and orientation of imitators. Taking into account the characteristics of EO dimensions and the specificity of imitative practices utilized by high-tech firms it appears to be possible to assign the fundamental features of EO not only to the technological pioneers.

Considering the first EO dimension, the innovation, and the accelerating pace of technology advancing a very popular phrase comes to mind - "innovate or die". Unfortunately, this is a somewhat misleading slogan suggesting existence of only one appropriate strategic path to success or even survival and disregarding imitation as an 
ineffective activity of minor importance. Meanwhile "imitation is not only as critical as innovation to business survival and prosperity but is also vital to the effective exercise of innovation itself" (Shenkar, 2010, p. 4). By imitating firms provide evidence that there is more than one way to move forward and those alternative pathways provide opportunities for further improvements and innovations (Shenkar, 2010). While most definitions and discussions in the literature might suggest that entrepreneurial firms implement only radical and original innovations, their actual activity in many cases focuses on modification of existing products, services, processes and their incremental improvements (Droege \& Dong, 2008, p. 55). Hence, working on existing products does not exclude the creativity and experimentation in searching for improvements that add significant value to the original product (Shenkar, 2010). "The subsequent improvements in an invention after it first introduction may be vastly more important economically, than the initial availability of the invention in its original form" (Kline, Rosenberg, 1996, p. 283, after: Fagerberg, 2005, p. 6). Those improvements, as presented in previous section of the article, can be introduced equally by original innovators and their followers. The results of Shenkar's (2010) research confirms that "imitation is not a mindless repetition, it's an intelligent search for cause and effect (Schenkar, 2010, p. 28). As Schmitz (1989) modeled, by implementing current knowledge through imitation entrepreneurs create new knowledge and "augment the existing stock of industry knowledge in a learning-by-doing fashion" (Schmitz, 1989, p. 724). Furthermore, in high-tech sectors it is often extremely difficult to clearly identify actual imitators and true original innovators. Developing complex electronic or software products involves a very broad sourcing from existing industry knowledge, to the extent that original innovations can and often do result from imitative activity (Park, 2005; Henkel \& Baldwin, 2009, pp. 30-31). Even widely acknowledged innovators such as IBM, Apple, Microsoft, General Electric are also consummate imitators that use imitation to outmaneuver innovative competitors and benefit economically from inventions made by others (Shenkar, 2010; Schnaars, 1994). A good example of multiple sourcing in software-intensive systems is Java programming language of Sun Microsystems. When Sun decided to change its product to an open source software it turned out to be a very tedious task as commented by Sun General Counsel Mike Dillon: "Java Standard Edition contains about 6 million lines of code. [...] Our legal team [of 190 lawyers] had to go over it, line by line, and look for all copyrights marks and third-party involvements. Where Sun didn't have the correct licenses, we had to contact the owners, one by one, and determine rights" (Henkel \& Baldwin, 2009, p. 29-30). In most cases the majority of profitable innovations introduced to high-technology markets contains a strong dose of imitation. The visible illustration is the large number of patent infringement suits against market leaders (Fischer, 2011). In the high-tech sectors inspiration goes in both directions - imitations are driven by innovations and creative imitations foster innovations. Moreover, a currently observed trend of utilizing open innovation systems undoubtedly will lead to further fusion of innovation and imitation by blurring already fuzzy boundaries between them (Najda-Janoszka, 2011). 
Nevertheless imitation is not always successful. Any form of a business activity is accompanied by risk of failure. Hence, the assumption that imitation reduces risk of the market entry is not always supported by the business practice. In fact, the follower strategy provides opportunity for lowering some kinds of risk (Schewe, 1996, p. 56) and at the same time substitutes for other types (Shenkar, 2010, p. 163). Research confirms that the costs of imitating are significantly lower than those incurred by innovators. A successful market entry performed by innovators requires higher expenditures by an average of 25 to 35 percent (Shenkar, 2010, p.161). Nevertheless costs incurred by the followers in high-tech industries are not trivial, since most successful imitators exhibit high levels of R\&D activity, develop new projects on their own in order to develop necessary startup experience for the new ventures (Schnaars, 1994). Converting technological innovations into a copy that will preserve the favorable outcome observed in the original requires specialized knowledge and capabilities providing the view inside the innovative solution and ways to overcome its causal ambiguity (Shenkar, 2010, p. 159). There are many cases of the imitation failure or underperformance due to the lack of adequate capabilities necessary to understand and further copy the new technology, because "if you fail to decipher causality in the original model, it is virtually impossible to establish causality in the recipient system" (Shenkar, 2010, p. 160). Therefore technological imitators take a considerable risk by investing time, effort and capital in replication projects which in a halfway through their execution may turn out to be unfeasible. Hence, rapid technology progress renders innovative technologies obsolete sometimes even before the potential imitator manages to replicate them. The risk of such unproductive use of time and resources while operating on a highly dynamic and competitive market might jeopardize the existence of a firm. Similarly as for pioneers heavy and often irreversible investment in a particular technology lowers the incentive to develop other solutions that might prove more promising and thus increases risk of future growth of the imitator (Shenkar, 2010, p. 164). Further, patented innovations drive up imitation costs by an average of 11 percent (Mansfield, Schwartz, Wagner, 1981 after: Schnaars, 1994, p. 29) and raise the legal risk of possible patent infringement suits. Although inventing around the patent due to disclosure of the invention is time-consuming and costly, it provides modifications that avoid patent infringements. But in high-tech industries "it is often impossible to identify with certainty all patents that the product might infringe" (Baldwin \& Henkel, 2009 , p. 30). Therefore, replicating and improving complex, multi-sourced technological solutions may be as risky in terms of possible legal allegations as walking through a minefield. Furthermore, entering the market with an imitation involves a substantial investment in marketing areas - market research, advertising, promotion, distribution in order to convince customers to the new features added to the innovation, to overcome the brand loyalty to the original product and to reduce risk of preserving the image of a copycat (Shenkar, 2010; Schnaars, 1994). Analogically as in case of a pioneer, a follower introducing an imitation to the dynamic and highly competitive technology market may have to face the numerous group of other followers that worked in parallel on the same technological solution. Moreover, as evidenced in the literature followers of 
pioneers are quite often further imitated and even surpassed by later entrants (Teece, 2002). Consequently innovators as well as imitators have to take into account the risk of imitation.

As presented in the previous part of the article entrepreneurial proactiveness has two features: an aggressive competition with rival firms and an organizational pursuit of favorable business opportunities (Kreiser, et al. 2002, p. 78). According to the literature high levels of competitive aggressiveness suggest implementing strategies based on imitation (Droege \& Dong, 2008, p. 57). Thus observed accelerating pace of imitation and highly competitive environment in high-tech sectors corresponds precisely to the formulated assumption. Imitators exhibiting high level of competitive aggressiveness invest heavily to quickly overcome the advantages of pioneers and structure their tactics to address any vulnerabilities in pioneers' value creation processes (Droege \& Dong, 2008, p. 57). Since competitive aggressiveness implies quick responses to rivals actions and pricing tactics modifications are the fastest to introduce they are the most common practice used by technology followers (Schnaars, 1994). In such dynamic and considerably hostile environment imitators operate under severe time and competitive pressure feeling the breath of other potential imitators and later entrants behind their back. Therefore imitators are less likely to become complacent, are more aware of game-changing technologies (Shenkar, 2010, p. 10). Technology imitators know that one innovative technology can give rise to multiple market opportunities (Shane, 2000). Proactiveness exhibiting in recognizing and sizing market opportunities does not require being first to the market (Lumpkin \& Dess, 1996). In high-tech sectors often "the most successful entrant is not the first firm to enter but the first to enter when demand explodes" (Schnaars, 1994, p. 200).

\section{Conclusions}

The research findings, theoretical discussions presented in the literature as well as the observed business practice support the assumption that high-technology imitators can be characterized by entrepreneurial orientation. Imitators often present a proactive attitude in searching and pursuing business opportunities based on competitors' offering and aiming at challenging their positions on the market. Hence, following a high-technology innovator is a considerably risky path to market success. Building on existing innovation allows for reduction of some kind of risks while substituting them for other types. The greater complexity, causal ambiguity of the novel, multisourced technology, the higher risk of imitation failure. Imitation and innovation are intertwined processes, thus pioneers as well as followers bear the risk of further imitation. Considering the last but the fundamental dimension of EO, it has been observed that "what we think as a single innovation is often result of a lengthy process involving many interrelated innovations" (Fagerberg, 2005, p. 6). This observation is especially valid in the high-tech environment, where developing complex solutions requires multi-sourcing from existing knowledge base to the extent that original innovations often result from imitative activity. In the high-tech sectors inspiration 
goes in both directions - imitations are driven by innovations and creative imitations foster innovations. Imitation often involves creativity, experimentation and knowledge creation in learning-by-doing fashion. The business practice exhibits a substantial impact of various imitative activities on knowledge diffusion and development of hightech industries.

Naturally, not all followers in high-tech sectors exhibit the entrepreneurial behavior since there are different kinds of imitative activity and all of those types are widely utilized in business practice. Unquestionably, the further on the creativity continuum, the higher probability of entrepreneurial orientation of an imitator. Moreover, a highly competitive and dynamic environment forces high-tech companies to engage in numerous often concurrent projects, and for each of those projects a different market entry strategy can by utilized. Therefore it is possible for a firm to be considered an innovator and imitator at the same time. Hence, it seems to be more appropriate to analyze imitation and innovation strategies by focusing not on the firm but on particular projects carried out by that firm. This leads to another important reflection. Assuming that innovative approach is not always the best choice and the high-tech firms need to engage in a wide range of projects, then it is crucial to develop and master entrepreneurial capabilities that allow for effective developing and implementing both market entry strategies. Implementing and utilizing those capabilities enable transforming the incidental approach to imitation into strategic one, which is necessary in the face of high competition, rapid technology advancing and development of open innovation systems in high-technology sectors.

\section{References}

Afuah, A. (2009). Strategic Innovation: New Game Strategies for Competitive Advantage, New York: Routledge.

Bednarczyk M. (red.). (2010). Przedsiębiorczość w turystyce. Zasady i praktyka, Warszawa, Wydawnictwa Fachowe CeDeWu.

Cefis E., Marsili O. (2011). Born to flip. Exit decisions of entrepreneurial firms in high-tech and low-tech industries. Journal of Evolutionary Economics, 21(3), 473-498.

Covin J.G., Slevin D.P. (1991). A conceptual model of entrepreneurship as firm behavior. Entrepreneurship Theory and Practice, 16(1), 7-25.

Droege, S.B., Dong L.C. (2008). Strategic entrepreneurship: imitation versus substitution. Journal of Small Business Strategy, 19(1), 51-62.

Fagerberg, J. (2005). Innovation: A Guide to the Literature. In: J. Fagerberg, D.C. Mowery,

R.R. Nelson (eds.). The Oxford Handbook of Innovation. New York: The Oxford University Press.

Fischer, T. (2011). Managing Value Capture: Empirical Analyses of Managerial Challenges in Capturing Value. Heidelberg: Gabler Verlag - Springer Fachmedien Wiesbaden GmbH. Grandstrand, O. (1980). Towards a theory of the technology-based firm. Research Policy, 27(5), 465-489. 
Henkel, J., Baldwin, C.Y. (2009). Modularity for Value Appropriation - Drawing the Boundaries of Intellectual Property. Harvard Business School Working Paper 09-097.

'High technology' and 'knowledge based services' aggregates based on NACE Rev.2, http://epp.eurostat.ec.europa.eu/cache/ITY_SDDS/Annexes/htec_esms_an3.pdf.

Khandwalla, P.N. (1977). Some top management styles, their context and performance. Organization \& Administrative Sciences, 7(4), 21-51.

Kreiser, P.M., Marino, L.D., Weaver, K.M. (2002). Assessing the Psychometric Properties of the Entrepreneurial Orientation Scale: a Multi-Country Analysis. Entrepreneurship Theory and Practice, 26(4), 71-94.

Lee,R.P., Zhou, K.Z. (2012). Is Product Imitation Good for Firm Performance? An Examination of Product Imitation Types and Contingency Factors. Journal of International Marketing, 20(3), 1-16.

Lindelof, P., Lofsten, H. (2006). Environmental hostility and firm behavior - an empirical examination of new technology-based firms on science parks. Journal of Small Business Management, 44 (3), 386-406.

Lumpkin, G. T., Dess, G. (1996). Clarifying the Entrepreneurial Orientation Construct and Linking it to Performance. Academy of Management Review, 21 (1), 135-172.

Luo, Y., Sun J., Wang, S.L. (2011). Emerging Economy Copycats: Capability, Environment, and Strategy. Academy of Management Perspectives, 25(2), 37-56.

Mansfield, E. (1985). How rapidly does new industrial technology leak out? The Journal of Industrial Economics, 34(2), 217-223.

Miller, D. (1983). The Correlates of Entrepreneurship in Three Types of Firms. Management Science, 29 (7), 770-791.

Miller, D., Friesen, P.H. (1983). Strategy-making and environment: The third link. Strategic Management Journal, 4, 221-235.

Najda-Janoszka, M. (2011). Zatrzymywanie wartości w sieciach kooperacyjnych przedsiębiorstw. Zeszyty Naukowe Uniwersytetu Ekonomicznego w Poznaniu, (169), $48-62$.

Palich, L.E., Bagby, D.R. (1995). Using Cognitive Theory to explain Entrepreneurial Risktaking: Challenging the conventional wisdom. Journal of Business Venturing, 10(6), 425-438.

Park, J.S. (2005). Opportunity recognition and product innovation in entrepreneurial hitech start-ups: a new perspective and supporting case study. Technovation, 25, 739752.

Schewe, G. (1996). Imitation as a strategic option for external acquisition of technology. Journal of Engineering and Technology Management, 13(1), 55-82.

Schmitz, J.A. (1989). Imitation, Entrepreneurship, and Long-Run Growth. Journal of Political Economy, 97(3), 721-739.

Schnaars, S.P. (1994). Managing imitation strategies, New York: The Free Press.

Shane, S. (2000). Prior knowledge and the discovery of entrepreneurial opportunities. Organizational Science, 11(4), 448-469.

Shenkar, O. (2010). Copycats, Boston: Harvard Business Press. 
Simon, M., Houghton, S.M., Aquino, K. (2000). Cognitive biases, risk perception, and venture formation: How individuals decide to start companies. Journal of Business Venturing, 15(2), 113-134.

Sorensen, J.B., Stuart, T.E. (2000). Aging, obsolescence, and organizational innovation. Administrative Science Quarterly, 45(1), 81-112.

Teece, D.J. (2002). Managing Intellectual Capital, New York: Oxford University Press.

Zahra, S.A. (1993). New product innovation in established companies: Associations with industry and strategy variables. Entrepreneurship Theory and Practice, 18(2), 47-69.

Zahra, S.A., Neubaum, D.O. (1998). Environmental adversity and the entrepreneurial activities of new ventures. Journal of Developmental Entrepreneurship, 3(2), 123-140.

\begin{abstract}
Polish)
Wielu badaczy potwierdza, że ze względu na wysoki poziom innowacyjności sektory wysokich technologii sq wyjątkowo adekwatnym obiektem badawczym w zakresie studiowania działań przedsiębiorczych. Niemniej jednak dynamika i niestabilność otoczenia w tych sektorach sprawia, że innowacja to nie zawsze najlepsza strategia wejścia na rynek. W rzeczywistości praktyka gospodarcza wskazuje na szerokie wykorzystanie strategii imitacji przez przedsiębiorców sektorów technologicznych. Tymczasem literatura poświęcona przedsiębiorczości skupiona jest niemal wyłacznie na oryginalnych innowatorach i radykalnych innowacjach marginalizujac znaczenie imitacji w procesie rozwoju na poziomie gospodarki, sektora jak $i$ indywidualnych przedsiębiorstw. Istnieje zatem wyraźny niedobór badań nad wykorzystaniem imitacji $w$ działaniach przedsiębiorczych. Dlatego niniejszy artykuł przedstawia dyskusję na temat możliwości przypisania przedsiębiorczej orientacji imitatorom funkcjonujq̨cych $w$ sektorach wysokich technologii.

Słowa kluczowe: imitacja, wysokiej technologii firmy, orientacja przedsiębiorcza.
\end{abstract}

